\title{
Renal cell Cancer, Environmental Arsenic Exposure and Carcinogenic Mutations
}

\author{
Bekir TANRIOVER \\ Columbia University College of Physicians \& Surgeons, Division of Nephrology, New York, New York, USA
}

\begin{abstract}
Malignant tumors of the kidney accounts for approximately 2-3\% of the all new primary cancers cases diagnosed in the US, with an estimated 60.000 cases occurring annually. Current epidemiological studies provide convincing evidence linking environmental arsenic exposure to an elevated risk of renal cell carcinoma (RCC). High levels of arsenic leaching from natural underground sources have contaminated newly drilled wells, leading to cancers of the skin, lung, liver, kidney, and bladder. This link has been the basis for regulatory actions. In 2002, the US Environmental Protection Agency (EPA) lowered the maximum contaminant level for the amount of arsenic allowed in drinking water from 50 ppb to $10 \mathrm{ppb}(10 \mu / \mathrm{L})$. In addition, recent molecular biology research on familial kidney cancer syndromes indicate that inactivation mutation in VHL tumor suppressor gene contributes to clear cell RCC development. Future studies using animal models are needed to explain genetic susceptibility in VHL mutations and carcinogenic effect of arsenic exposure.
\end{abstract}

Keywords: Arsenic, Environmental exposure, Renal cell carcinoma

OZET

\section{Böbrek Kanserinin Gelişiminde Arsenik ve Karsinojenik Mutasyonların Rolü}

Amerika Birleşik Devletleri'nde her sene 60,000 civarında yeni böbrek kanserine tanı konulmakta ve bu bütün kanserlerin \%2-3'ünü oluşturmaktadır. Epidemiyolojik araştırmalar, çevresel arseniğe maruz kalanlarda böbrek kanser riskinin artı̆̆ını göstermişlerdir. Bu araştırmalar, daha çok içme suyu kuyudan temin edilen kırsal alanlarda ve az gelişmiş ülkelerde yapıımış ve arseniğe kronik olarak 10 ppb (10 $\mu \mathrm{g} / \mathrm{L})$ ' den daha fazla konsantrasyonlarda maruz kalanlarda gosterilmiştir. Günümüze kadar molekuler seviyede arsenik toksisitesinin karsinojenik ve mutagenik etkisi henüz çalışımamıştır. Diğer taraftan, ailesel böbrek kanseri (von Hippel-Lindau sendromu) olan hastalarda yapılan genetik çalışmalar, VHL tumor supresor genindeki inaktivasyon mutasyonunun en sık rastlanan böbrek kanser çesidi olan şeffaf hücreli kansere sebep olduğu gosterilmiştir. Sık rastlanan bir halk sağlığı problemi olması itabariyle, gelecekte hayvan modelleriyle VHL mutasyonu ve arseniğin kanserojenik etkisinin çalışılması önemli bir araştırma konusu olarak yerini korumaktadır.

Anahtar Kelimeler: Arsenik, Çevresel maruziyet, Renal hücreli karsinom 


\section{BACKGROUND}

RCCs, which originate within the renal cortex, are responsible for 80 to $85 \%$ of all primary renal neoplasms and $3 \%$ of all adult malignant neoplasms with a male to female ratio $3: 2 .^{1}$ Several distinct subtypes of RCC have been identified based on their morphology, growth pattern, cell of origin, histochemical, and molecular basis including clear cell (75 to 85 percent of tumors), papillary (chromophilic) (10 to 15 percent), chromophobic (5 to 10 percent), oncocytic (uncommon), collecting duct (Bellini's duct) (very rare). ${ }^{2}$ In 2010, approximately 61,000 people expected to be diagnosed and about 13,000 would die from RCC in the United States (US) $;{ }^{1}$ worldwide, there were an estimated 270.000 cases and 116.000 deaths in $2008 .^{3}$ The incidence varies widely from region to region with the highest rates observed in Scandinavia and North America. Although the incidence is lower in Africa, whites and blacks appear to be equally affected in the United States.

The incidence of RCC in the US has increased over time. ${ }^{4}$ Between 1975 and 1995, the incidence rates per 100.000 person-years increased by $2.3,3.1,3.9$ and 4.3 percent annually for white men, white women, black men, and black women, respectively. ${ }^{5}$ More recent data from 1997 to 2007 showed a similar trend with 2.6 percent increased yearly incidence (http://www.seer.cancer.gov/statfacts/html/kidrp .html). Part of the increase in incidence may be explained by the greater number of asymptomatic tumors detected as a result of widespread use of noninvasive abdominal imaging modalities. In the 1970s, approximately 10 percent of RCCs were discovered incidentally, compared to 60 percent in 1998. ${ }^{6}$ Although most RCCs are sporadic, several syndromes, such as von Hippel-Lindau (VHL), associated with RCC have been described. Factors that favor a hereditary contribution in patients without a clear genetic disease include first degree relatives with a tumor, onset before the age of 40 , bilateral or multifocal disease, and abnormalities on chromosome 3 ? $^{\text {? }}$

A number of environmental and clinical factors have been implicated in the etiology of RCC. ${ }^{8}$ These include smoking, hypertension, occupational exposure to toxic compounds, obesity, acquired cystic disease of the kidney (typically associated with di- alysis), analgesic abuse nephropathy, genetic predisposition, and environmental exposures (arsenic in groundwater sources). In more recent years, attention to chronic exposures of arsenic found in drinking water has grown. In some locations, this contamination presents an enormous health hazard, as in the case of the ongoing epidemic of arsenic poisoning in West Bengal, India, and Bangladesh.'${ }^{11}$ High levels of arsenic leaching from natural underground sources have contaminated newly drilled wells, leading to more than one million people drinking arsenic-contaminated water (above $50 \mu / \mathrm{L}$ ). Thousands of people living there have been found to have arsenic-related skin lesions, liver problems, and neuropathy. The "HEALS" cohort found that chronic arsenic exposure through drinking water $(>150 \mu / \mathrm{L})$ was associated with increased all-cause mortality (HR 1.68, 95\% CI 1.26-2.23) and increased cardiovascular mortality (HR 1.92, 95\% 1.073.43) over seven year follow-up. ${ }^{12}$ The greater focus of the United States and other countries has been on the potential long-term adverse health outcomes from chronic exposures to much lower doses of arsenic in drinking water that could lead to future increased risk of cancer. There are many epidemiological studies and case reports showing an association between arsenic exposure and cancer. ${ }^{13-18}$ Arsenic exposure is associated with cancers of the skin, lung, liver, kidney, and bladder. This link has been the basis for regulatory actions. In 2002, the US Environmental Protection Agency (EPA) lowered the maximum contaminant level for the amount of arsenic allowed in drinking water from $50 \mathrm{ppb}$ to 10 ppb $(10 \mu / \mathrm{L})$ based upon review of carcinogenic risks (http://water.epa.gov/lawsregs/rulesregs).

\section{CURRENT RESEARCH}

Several ecological studies of arsenic exposure have found elevated rates of kidney cancer in areas with high exposure to arsenic in groundwater sources. Wu et al. observed a significant dose-response relation between arsenic levels in well water (determined in1964 and 1966) and mortality rates for cancers of the bladder, kidney, skin, and lung in both males and females, and cancers of the prostate and liver in males in 42 villages of the southwestern coast of Taiwan between 1973 and $1986 .{ }^{16}$ 
Chen et al. studied the same population in the southwest region of Taiwan and compared the cancer potency index of various internal organs induced by ingested inorganic arsenic in drinking water. ${ }^{19}$ The arsenic levels in drinking water were stratified into $<0.10 \mathrm{ppm}, 0.10-0.29 \mathrm{ppm}, 0.30-0.59 \mathrm{ppm}$ and 0.60 or more ppm. In total, there were 30 male and 34 female kidney cancer deaths occurred during the study period. Potency index of developing cancer in the kidney due to an intake of $10 \mu \mathrm{g} / \mathrm{kg} /$ day of arsenic was $4.2 \times 10^{-3}$ for males as well as $4.8 \times 10^{-3}$ for females in the study area. The risk for males and females was practically identical within a twofold range of magnitude indicating no gender difference in arsenic-induced carcinogenic responses. Furthermore, the cancer potency index was within a fourfold range of magnitude for kidney. The residents of the study areas had consumed high arsenic artesian well water since 1910 . The arsenic concentration of this water, measured in the early 1960s, ranged from 0.35 to $1.14 \mathrm{ppm}$, with a median of 0.78 ppm. A tap water system was implemented in the region in the early 1960s and nearly all Blackfoot disease - endemic areas (the southwest region of the Taiwan) were supplied by municipal water between 1965 and 1975. Artesian water was no longer used for drinking and cooking after mid-1970s. Yang et al. examined kidney cancer mortality after the elimination of arsenic exposure from the artesian well water in the same region. They measured the standardized mortality ratios (SMR) for kidney cancer for the Blackfoot-endemic area for the years 1971-2000..$^{20}$ Time trends of SMRs for kidney cancer had showed gradually decline from 1506 to 329 for male and from 1630 to 521 for female for 3-year periods between 1971 and 2000. The estimated slope for male SMRs in the linear time trend analysis was $-15.13(\mathrm{p}<0.01)$ for men and $-24.43(\mathrm{p}<$ 0.01 ) for women. The authors concluded that the association of arsenic exposure with kidney cancer was likely causal.

Hopenhayn-Rich et al conducted a similar study between 1986 and 1991 in 26 counties of Cordoba, Argentina (estimated population 2.7 millions) where there has been a well-documented history of arsenic exposure from well water drinking. ${ }^{21}$ They investigated mortality from lung, kidney, liver, and skin cancers in counties which were categorized into low (40-140 $\mu \mathrm{g} / \mathrm{L})$, medium (140-178 $\mu \mathrm{g} / \mathrm{L})$ and high (> $178 \mu \mathrm{g} / \mathrm{L})$ arsenic exposure areas. The water analysis for arsenic measurement performed in 1930, 1968 and 1985. SMR was calculated using all of Argentina as the reference population. A significant dose-response relation in SMR from low to high exposure were observed for kidney cancer $(0.87,1.57$ for men and 1.00 and 1.87 for women, respectively, $\mathrm{p}<0.001$ ).

Kurttio et al. assessed the effect of low level of arsenic exposure (median 0.1-0.5 $\mu \mathrm{g} / \mathrm{L}$ ) from drilled wells in Finland and studied the association between arsenic exposure and the risk of bladder and kidney cancers. ${ }^{22}$ The study population was selected from a register-based cohort of all Finns who had lived at an address outside the municipal drinking water system during 1967-1980 $(n=144,627)$. The final study population consisted of 61 bladder cancer cases, 49 kidney cancer cases diagnosed between 1981 and 1995 and age and sex matched random sample reference cohort $(n=275)$. The well- water samples were collected between July and November 1996 for arsenic measurements. 50th percentile arsenic exposure among the cases and the reference group was $0.1 \mu \mathrm{g} / \mathrm{L}$ and $0.1 \mu \mathrm{g} / \mathrm{L}$ for arsenic concentration in well water, $0.2 \mu \mathrm{g}$ and $0.2 \mu \mathrm{g}$ for daily dose of arsenic from well water, and 9 years and 10 years for duration of well use before 1980, respectively. They found no evidence for association between low level arsenic exposure (arsenic concentration, daily dose and cumulative dose) and kidney cancer (RR 0.78 and 95\% CI 0.37-1.66 for the concentration of arsenic in water 01.-0.5 $\mu \mathrm{g} / \mathrm{L}$ ). In this study, the arsenic exposure was extremely low compared to other studies. In the United States, drinking water generally contains an average of 2 $\mu \mathrm{g} / \mathrm{L}$ of arsenic, although 12 percent of water supplies from surface water sources in the North Central region of the country and 12 percent of supplies from ground water sources in the Western region have levels exceeding $20 \mu \mathrm{g} / \mathrm{L}$ (available from: www.atsdr.cdc.gov/tox profiles/tp.asp?id= 22\&tid=3)

Huang et al. ${ }^{23}$ explored the relationship of urinary total arsenic level and estimated glomerular filtration rate (eGFR) on the risk of RCC in low arsenic exposure area. They conducted a case control study between 2006 and 2009 with 132 patients with RCC, and 260 sex and age matched controls from 
the hospital based pool in the National Taiwan University Hospital. The majority of the study participants lived in Taipei City and drank tap water from the Taipei Water Department in which average arsenic concentration is $0.7 \mu \mathrm{g} / \mathrm{L}$. Spot urine samples were collected to measure total urinary arsenic level and arsenic species including As3, As5, MMA5, DMA5. They concluded that higher urinary arsenic level (> $15.95 \mu \mathrm{g} / \mathrm{g}$ creatinine) was a strong predictor of RCC, and low eGFR $(<60$ $\mathrm{ml} / \mathrm{min} / 1.73 \mathrm{~m}^{2}$ ) and hypertension interact with urinary total arsenic in modifying the risk of RCC (multivariate adjusted OR $6.01,95 \%$ CI 2.26$16.04, \mathrm{p}<0.001)$. A trend test indicated that the risk of RCC increased along with the accumulating number of these 3 risk factors in a dose-response relationship ( $\mathrm{p}<0.0001)$.

Aside from these convincing epidemiological data, major advances have been made over the last two decades in understanding the molecular biology and pathogenesis of RCC. Molecular analyses of clear cell RCCs often reveal chromosomal losses in the genetic area spanning 3 p14 to 3 p26. ${ }^{24-26}$ The genetic abnormality in VHL has also been localized to a similar area, 3 p25 to 3 p26. These findings suggest that a common genetic abnormality may underlie the pathogenesis of both disorders. VHL gene plays a pivotal role in the development of clear cell RCC in patients with VHL disease. Its gene product, pVHL, functions as a tumor suppressor protein and targets several proteins for degradation by proteasomes. ${ }^{26,27}$ Abnormalities of the VHL gene are also found in 50 to 60 percent of patients with sporadic RCC, suggesting that the VHL gene has a role in pathogenesis in this setting as well. Among $187 \mathrm{pa}-$ tients with sporadic RCC, somatic mutations or promoter hyper-methylation in the VHL gene were observed in 58 percent of cases. ${ }^{28}$ Innovative, highthroughput methods have improved the detection of VHL abnormalities, and genetic or epigenetic alteration of the VHL gene may be present in as many as 90 percent of cases..$^{29} \mathrm{~A}$ "two-hit" model has been validated for VHL associated tumors which requires inactivation of VHL tumor suppressor protein through somatic events and an environmental exposure. There is a possibility that arsenic exposure in the presence of VHL gene mutation may play a significant role as a carcinogen.
A factor that has impeded research on the carcinogenic aspects of arsenic is the absence of a clearly defined animal model of the effects of arsenic exposure. The use of laboratory animals with analytic research designs on this topic would make possible studies that cannot be carried out with humans..$^{30}$

\section{CONCLUSION}

Current epidemiological studies provide convincing evidence linking environmental arsenic exposure to an elevated risk of RCC. Different level of arsenic exposure and other comorbidities including smoking, obesity, hypertension, chronic kidney disease may explain a part of geographic variation in RCC incidence worldwide. Efforts should be taken to reduce exposures to inorganic arsenic from both naturally occurring and man-made sources.

The multifactorial nature of RCC requires that additional work needs to be done to elucidate the complex relationships between potential genetic and environmental factors on cancer development. Major advances have been made over the last two decades in understanding the biology of VHL geneassociated tumors such as clear cell RCC. Inactivation mutations in this tumor suppressor gene play a major role to develop RCC in the presence of environmental exposure, "two-hit" model. Future studies using animal models are needed to explain genetic susceptibility in VHL mutations and carcinogenic effect of arsenic exposure.

\section{REFERENCES}

1. Siegel R. Cancer statistics, 2011: the impact of eliminating socioeconomic and racial disparities on premature cancer deaths. CA Cancer J Clin 61: 212-236, 2011.

2. Patard JJ. Prognostic value of histologic subtypes in renal cell carcinoma: a multicenter experience. J Clin Oncol 23: 2763-2771, 2005.

3. Ferlay J.Estimates of worldwide burden of cancer in 2008: GLOBOCAN 2008. Int J Cancer 127: 2893$917,2010$.

4. Stafford HS. Racial/ethnic and gender disparities in renal cell carcinoma incidence and survival. J Urol 179:1704-1708, 2008.

5. Chow WH. Rising incidence of renal cell cancer in the United States. JAMA 281: 1628-1631, 1999. 
6. Pantuck AJ, Zisman A, Belldegrun AS. The changing natural history of renal cell carcinoma. J Urol 166: 1611-1623, 2001.

7. van Kessel AG. Renal cell cancer: chromosome 3 translocations as risk factors. J Natl Cancer Inst 91: 1159-1160,1999.

8. Moore LE, Wilson RT, Campleman SL. Lifestyle factors, exposures, genetic susceptibility, and renal cell cancer risk: a review. Cancer Invest 23: 240-255, 2005.

9. Smith AH. Lingas EO, Rahman M. Contamination of drinking-water by arsenic in Bangladesh: a public health emergency. Bull World Health Organ 78: 10931103, 2000.

10. Chakraborti D. Arsenic groundwater contamination in Middle Ganga Plain, Bihar, India: a future danger? Environ Health Perspect 111: 1194-1201, 2003.

11. Chowdhury UK. Groundwater arsenic contamination in Bangladesh and West Bengal, India. Environ Health Perspect 108: 393-397, 2000.

12. Argos M. Arsenic exposure from drinking water, and all-cause and chronic-disease mortalities in Bangladesh (HEALS): a prospective cohort study. Lancet 376: 252-258, 2010.

13. Cuzick JP, Sasieni S, Evans S. Ingested arsenic, keratoses, and bladder cancer. Am J Epidemiol 136: 417 421, 1992.

14. Chiou HY. Incidence of internal cancers and ingested inorganic arsenic: a seven-year follow-up study in Taiwan. Cancer Res 55: 1296-1300, 1995.

15. Marshall G. Fifty-year study of lung and bladder cancer mortality in Chile related to arsenic in drinking water. J Natl Cancer Inst 99: 920-928, 2007.

16. Wu MM. Dose-response relation between arsenic concentration in well water and mortality from cancers and vascular diseases. Am J Epidemiol 130: 11231132, 1989.

17. Chen CJ, Wang CJ. Ecological correlation between arsenic level in well water and age-adjusted mortality from malignant neoplasms. Cancer Res 50: 54705474, 1990.

18. Chen CJ. Malignant neoplasms among residents of a blackfoot disease-endemic area in Taiwan: high-arsenic artesian well water and cancers. Cancer Res 45: 5895-5899, 1985.

19. Chen CJ. Cancer potential in liver, lung, bladder and kidney due to ingested inorganic arsenic in drinking water. Br J Cancer 66: 888-892, 1992.

20. Yang CY. Reduction in kidney cancer mortality following installation of a tap water supply system in an arsenic-endemic area of Taiwan. Arch Environ Health 59: 484-488, 2004.

21. Hopenhayn-Rich C, Biggs ML, Smith AH. Lung and kidney cancer mortality associated with arsenic in drinking water in Cordoba, Argentina. Int J Epidemiol 27: 561-569, 1998.
22. Kurttio P. Arsenic concentrations in well water and risk of bladder and kidney cancer in Finland. Environ Health Perspect 107: 705-710, 1999.

23. Huang CY. Effect of urinary total arsenic level and estimated glomerular filtration rate on the risk of renal cell carcinoma in a low arsenic exposure area. J Urol 185: 2040-2044, 2011.

24. Maher ER, Yates JR. Familial renal cell carcinoma: clinical and molecular genetic aspects. $\mathrm{Br} \mathrm{J}$ Cancer 63: 176-179, 1991.

25. Latif $F$. Identification of the von Hippel-Lindau disease tumor suppressor gene. Science 260: 1317-1320, 1993.

26. Kim WY, Kaelin WG. Role of VHL gene mutation in human cancer. J Clin Oncol 22: 4991-5004, 2004.

27. Barry RE, Krek W. The von Hippel-Lindau tumour suppressor: a multi-faceted inhibitor of tumourigenesis. Trends Mol Med 10: 466-472, 2004.

28. Yao M. VHL tumor suppressor gene alterations associated with good prognosis in sporadic clear-cell renal carcinoma. J Natl Cancer Inst 94: 1569-1575, 2002.

29. Nickerson ML. Improved identification of von HippelLindau gene alterations in clear cell renal tumors. Clin Cancer Res 14: 4726-4734, 2008.

30. Abernathy CO. Arsenic: health effects, mechanisms of actions, and research issues. Environ Health Perspect 107: 593-597, 1999.

\section{Correspondence}

Bekir TANRIOVER, M.D.

Columbia University

College of Physicians \& Surgeons

Division of Nephrology

622 West 168th Street PH 4-124

New York, NY 10032

USA

e-mail: bt2294@columbia.edu 